\title{
PERSIAPAN DETEKSI PLAT DENGAN MODIFIKASI METODE VIOLA JONES KNN
}

\author{
Jati Purnomo dan Maukar \\ Universitas Gunadarma, Indonesia \\ Email: Jatipurnomo44@yahoo.co.id dan maukar@staff.gunadarma.ac.id
}

\begin{abstract}
Currently the system of automatic number plate recognition (ALPR, automatic license plate recognition) has started from anywhere in the country. Letter Plate there is a picture of the license plate number of the vehicle and then an image of the result of the algorithm for shopping alpha numerical images into text format. Although it may seem easy for humans, it turns out that plate detection is very complicated with computers while there are some location-related problems with, point of view, light, and occlusion. The purpose of this study is to know the results of the Can Plate Method Viola Jones KNN. This research methods the Viola Jones method (HaarCasscade) to build a plate detection system using the Python 3.0 programming language as well as the Open CV library. The information that lies in plate detection (from the way of insertion to completion and its supporting language programs) is minimal research in this field. At this stage, research can be done directly on the vehicle license plate object.
\end{abstract}

Keywords: plate detection; python; viola jones; KNN; vehicle type vehicles

\begin{abstract}
Abstrak
Saat ini sistem pengenalan plat nomor secara otomatis (ALPR, automatic license plate recognition) sudah mulai digunakan di berbagai negara. Deteksi Plat adalah menangkap gambar plat nomor kendaraan dan kemudian gambar diproses melalui beberapa algoritma untuk menyediakan konversi alfa numerik gambar ke dalam format teks. Meskipun tampak mudah dilakukan oleh manusia, ternyata pendeteksian plat sangat rumit dilakukan oleh komputer karena terdapat beberapa kesulitan yang terkait dengan lokasi, sudut pandang, cahaya, dan oklusi. Tujuan penelitian ini adalah untuk hasil deteksi Plat Modifikasi Metode Viola Jones KNN. Penelitian ini menerapkan metode Viola Jones (HaarCasscade) untuk membangun sistem deteksi plat dengan menggunakan bahasa pemrograman Python 3.0.serta library Open CV. Keterbatasan informasi terhadap plat detection (dari cara persipan sampai finishing serta bahasa program pendukungnya) membuat minimnya penelitian pada bidang ini. Persiapan pada tahap ini dapat dilanjutkan penelitian secara langsung pada objek plat jenis kendaraan bermotor.
\end{abstract}

Kata Kunci: deteksi plat ; python; viola jones; KNN; jenis kendaraan bermotor

\begin{tabular}{ll}
\hline How to cite: & Purnomo, Jati. dan Maukar (2021) Persiapan Deteksi Plat dengan Modifikasi Metode Viola Jones \\
E-ISSN: & KNN, Syntax Idea 3(4). http://dx.doi.org/10.36418/syntax-idea.v572 \\
Published by: & 2684-883X \\
\hline
\end{tabular}




\section{Pendahuluan}

Kendaraan merupakan salah satu hal terpenting dalam kehidupan manusia. Kendaraan merupakan alat transportasi untuk bepergian kemanapun yang kita inginkan. Kendaraan juga menjadi sasaran penjahat untuk melakukan pencurian terhadap kendaraan tersebut, maupun menyalahgunakan kendaraan untuk berbuat kejahatan khususnya pada perumahan (Muchtar \& Said, 2019)

Saat ini sistem pengenalan plat nomor secara otomatis $(A L P R$, automatic license plate recognition) sudah mulai digunakan di berbagai negara. Deteksi Plat adalah menangkap gambar plat nomor kendaraan dan kemudian gambar diproses melalui beberapa algoritma untuk menyediakan konversi alfa numerik gambar ke dalam format teks (Hidayah, 2017). Sistem ini pun dapat diimplentasi untuk banyak hal mulai dari parking system, meningkatkan ketertiban lalu-lintas, sampai membantu pencarian pelaku penculikan yang melarikan diri menggunakan mobil dengan plat nomor yang dikenal. untuk mendeteksi kepadatan lalu lintas pada persimpangan jalan (Abbas, Tayyab, \& Qadri, 2013) juga mendeteksi pelanggaran dalam berlalu lintas (Wang, Meng, Zhang, Lu, \& Du, 2013). Pengenalan plat nomor di Indonesia biasanya digunakan pada sistem parkir yangmasih dilakukan secara manual,yaitu dengan mencatat karakter plat nomor oleh petugasjaga parkir (Ruslianto \& Harjoko, 2011).

Tanda nomor kendaraan bermotor (TNKB) atau yang biasa disebut dengan plat nomor polisi adalah plat terbuat dari alumunium yang menunjukkan tanda kendaraan bermotor di Indonesia yang telah didaftarkan pada Kantor Samsat (Fitriawan, Pucu, \& Baptista, 2012).

Tanda Nomor Kendaraan Bermotor atau TNKB merupakan identitas atau kode unik yang menjadi pengenal sebuah kendaraan bermotor. TNKB sebuah kendaraan terdiri dari baris yang pertama terdiri dari huruf yang menunjukkan kode wilayah, biasanya merupakan area Karesidenan sebuah wilayah administratif yang terdiri dari beberapa kabupaten (Wakhidah, 2012).

Pengenalan plat nomor di Indonesia biasanya digunakan pada sistem parkir yang masih dilakukan secara manual, yaitu dengan mencatat karakter plat nomor oleh petugas jaga parkir. Padahal pengenalan plat nomor tidak hanya dilakukan untuk system perparkiran tetapi dapat digunakan untuk menemukan kendaraan yang melanggar peraturan lalu lintas dijalan raya secara real time, misalnya pelaku tabrak lari pada kecelakaan maupun kendaraan yang melanggar rambu-rambu lalu lintas (Ruslianto \& Harjoko, 2011).

Pengenalan plat nomor merupakan salah satu teknologi penting pada Sistem Lalu Lintas Cerdas (Shih, Chen, Chen, \& Kuo, 2012). Teknologi ini memanfaatkan pengolahan citra untuk mengidentifikasi kendaraan dari citra plat nomornya (Singh \& Randhawa, 2014). Namun keragaman pada plat dan lingkungan sekitarnya seperti ukuran font, jenis font, warna font, lokasi plat nomor, dan perbedaan intensitas karena lampu atau lingkungan dapat menyebabkan masalah pada saat pengenalan plat nomor (Singh \& Randhawa, 2014). 
E-enforcement Mendeteksi plat ganjil genap bentuk, warna, ukuran, dan font plat nomor berbeda di tiap negara dan sebuah aplikasi yang baik harus diadaptasi khusus untuk sistem di sebuah negara. Kadang sistem ini juga harus mengenali sistem dari negara lain, contohnya di berbagai negara Eropa yang berdekatan berbagai mobil dari negara tetangga dapat dengan mudah melintasi batas sebuah negara. Untuk penggunaan di Indonesia yang merupakan negara kepulauan (jumlah lalu lintas mobil antar pulau terbatas), sistem bisa dioptimasi untuk mengenali plat yang umum di wilayah atau pulau tertentu. Identifikasi plat merupakan Langkah pertama yang dilakukan sehingga keberadaannya sangat vital. Mudah saja bagi manusia untuk mengetahui letak dimana plat berada atau itukah plat atau bukan; tetapi, tugas ini akan sangat sulit dilakukan bagi komputer dikarenakan terdapat beberapa kompleksitas yang terkait dengan lokasi, sudut pandang, cahaya, dan oklusi (Suharyo, Rosyid, Promotor, \& Armono, 2017).

Algoritma Haar Cascade Classifier adalah salah satu algoritma yang digunakan untuk mendeteksi sebuah wajah. Algoritma tersebut mampu mendeteksi dengan cepat dan realtime sebuah benda termasuk wajah manusia. Algoritma Haar Cascade Classifier memiliki kelebihan yaitu perihal komputasi yang cepat karena tersebut hanya bergantung pada jumlah piksel dalam persegi dari sebuah image (Abidin, 2018).

Algoritma Haar Cascade merupakan salah satu model machine learning yang kerap kali digunakan sebagai pondasi aplikasi object detection dalam sebuah gambar maupun video. Algoritma ini lahir dari gagasan Paul Viola dan Michael Jones yang tertuang dalam paper berjudul " Rapid Object Detection using a Boosted Cascade of Simple Features” 2001. Metode Viola Jones diciptakan oleh Paul Viola dan Michael Jones pada tahun 2001 (Rahmadhika \& Thantawi, 2021).

Tujuan penelitian ini untuk m mengimplementasikan algoritma metode Viola Jones (haar Casscade) sebagai deteksi plat, KNN sebagai ekstraksi Teks pada artikel ini implementasi metode tersebut ke dalam sistem yang dibuat menggunakan bahasa pemrograman Python beserta library Open CV 2.7 (Open Source Computer Vision Library.

\section{Metode Penelitian}

Metode yang digunakan dalam penelitian ini adalah melakukan analisa prinsip kerja metode Haar Casscade, image input yang diproses akan disegmentasi atau diambil bagian plat nomornya saja menggunakan model harcascade yang telah dibuat Setelah gambar terfokus pada bagian plat nomor saja dilakukanlah praprocessing, dengan memaksimalkan kontras dan penghalusan citra dengan gaussian blur, Langkah selanjutnya adalah mendeteksi karakter yang terdapat pada plat nomor kendaraan. program ini mendeteksi seluruh kontur pada citra, Kontur yang telah didapatkan akan di filter dengan menyaring kontur yang benar benar memiliki karakteristik seperti huruf dan angka kemudian mengelompokannya sesuai dengan kemiripan ukuran dengan karakter lain. 


\section{Hasil dan Pembahasan}

Hasil data ini berupa data tabel dimana melewati pengujian segmentasi Plat dan Pengujian Karakter. Terdapat 3 penilaian dari hasil pengenalan karakter, yakni cocok, Kurang dan gagal. Dikatakan "Cocok" apabila program dapat menghasilkan data teks dengan benar sesuai dengan karakter dalam plat nomor yang di ujikan. Dikatakan "Kurang" karena program sudah dapat menghasilkan data teks sesuai dengan karakter dalam plat nomor yang di ujikan, akan tetapi masih ada beberapa karakter lain yang ikut terdeteksi, hal ini diakibatkan karena nilai masing-masing diagonal memiliki nilai yang hampir sama. Pengenalan dikatakan "Gagal" apabila dalam program tidak dapat menghasilkan data teks karakter dalam plat nomor yang di uji dengan benar. Pada penelitian ini Posisi tiang kamera $115 \mathrm{sd} 130 \mathrm{~cm}$, dan kemiringan sudut pengambilan gambar $200 \mathrm{sd} 450$, plat ideal berada antara jarak dari kamera ke plat $30 \mathrm{sd} 60 \mathrm{~cm}$. Saat posisi kurang dari $20 \mathrm{~cm}$, gambar plat tidak sempurna, dan saat posisi lebih dari $30 \mathrm{~cm}$, karakter plat terlalu kecil.

Tabel 1

Hasil Pengujian Plat

\begin{tabular}{ccl}
\hline No & No Plat & Deteksi Plat \\
\hline 1 & E3957NL & SUKSES \\
\hline 2 & B3972UKW & SUKSES \\
\hline 3 & B3105ULO & SUKSES \\
\hline 4 & B3516UAF & SUKSES \\
\hline 5 & B3215UFF & SUKSES \\
\hline 6 & B4695BL & SUKSES \\
\hline 7 & B6262UFH & SUKSES \\
\hline 8 & B6238UVM & SUKSES \\
\hline 9 & B3848ULJ & SUKSES \\
\hline 10 & B4476BBF & SUKSES \\
\hline 11 & B3379UGH & SUKSES \\
\hline 12 & B3507UAI & SUKSES \\
\hline 13 & B3355UFS & SUKSES \\
\hline 14 & B6607KTQ & SUKSES \\
\hline 15 & B3748UTM & SUKSES \\
\hline 16 & B3810UPY & SUKSES \\
\hline 17 & B3097UOO & SUKSES \\
\hline
\end{tabular}

Tabel 2

Hasil Pengujian Karakter

\begin{tabular}{cccccc}
\hline \multirow{2}{*}{ No } & \multirow{2}{*}{ No Plat } & \multirow{2}{*}{ KNN } & \multicolumn{3}{c}{ Karakter } \\
\cline { 4 - 6 } & & Ekstraksi & Gagal & Cocok & Kurang \\
\hline 1 & E3957NL & 3957NL & E & 3957NL & \\
\hline 2 & B3972UKW & I3972UKWJ & J & 3972UKW & B \\
\hline 3 & B3105ULO & 83105UL8 & & 3105UL & B, O \\
\hline 4 & B3516UAF & 8356UAF & 1 & 356UAF & B \\
\hline
\end{tabular}




\begin{tabular}{|c|c|c|c|c|c|}
\hline \multirow{2}{*}{ No } & \multirow{2}{*}{ No Plat } & \multirow{2}{*}{$\begin{array}{c}\text { KNN } \\
\text { Ekstraksi }\end{array}$} & \multicolumn{3}{|c|}{ Karakter } \\
\hline & & & Gagal & Cocok & Kurang \\
\hline 5 & B3215UFF & B325UFF & 1 & B325UFF & \\
\hline 6 & B4695BL & $846956 \mathrm{~L}$ & $\mathrm{~L}$ & $4695 \mathrm{~L}$ & $\mathrm{~B}, \mathrm{~B}$ \\
\hline 7 & B6262UFH & B9262UFH & 6 & B262UFH & \\
\hline 8 & B6238UVM & $\mathrm{A} 6238 \mathrm{U}$ & & $6238 \mathrm{U}$ & $\mathrm{B}, \mathrm{V}, \mathrm{M}$ \\
\hline 9 & B3848ULJ & 3048ULJ & B & 3048ULJ & \\
\hline 10 & B4476BBF & $\mathrm{I} 441611 \mathrm{~F}$ & & $44 \mathrm{~F}$ & $\begin{array}{c}\mathrm{B}, 7,6, \\
\mathrm{~B}, \mathrm{~B}\end{array}$ \\
\hline 11 & B3379UGH & 619UC & $33 \mathrm{H}$ & $9 \mathrm{U}$ & $\mathrm{B}, 7, \mathrm{G}$ \\
\hline 12 & B3507UAI & I35Q7UA1 & & $357 \mathrm{UA}$ & $\mathrm{B}, 0, \mathrm{I}$ \\
\hline 13 & B3355UFS & 8335IWF & $\mathrm{S}$ & $335 \mathrm{~F}$ & $\mathrm{~B}, \mathrm{~S}, \mathrm{U}$ \\
\hline 14 & B6607KTQ & 66607K1QIY & & $6607 \mathrm{KQ}$ & $\mathrm{B}, \mathrm{T}$ \\
\hline 15 & B3748UTM & I8374IW7V & & 374 & $\begin{array}{c}\mathrm{B}, 8, \mathrm{U}, \\
\mathrm{I}, \mathrm{M}\end{array}$ \\
\hline 16 & B3810UPY & A3118QPY1 & $\mathrm{B}, 8$ & 3PY & $10 \mathrm{U}$ \\
\hline 17 & B3097UOO & 0 & B3097UOO & & \\
\hline
\end{tabular}

\section{Kesimpulan}

Keterbatasan informasi terhadap plat detection (dari cara persipan sampai finishing serta bahasa program pendukungnya) membuat minimnya penelitian pada bidang ini. Persiapan pada tahap ini dapat dilanjutkan penelitian secara langsung pada objek plat jenis kendaraan bermotor. 


\section{BIBLIOGRAFI}

Abbas, Naeem, Tayyab, Muhammad, \& Qadri, M. Tahir. (2013). Real time traffic density count using image processing. International Journal of Computer Applications, 83(9), 16-19.Google Scholar

Abidin, Suhepy. (2018). Deteksi Wajah Menggunakan Metode Haar Cascade Classifier Berbasis Webcam Pada Matlab. Jurnal Teknologi Elekterika, 15(1), 21-27. Google Scholar

Fitriawan, Helmy, Pucu, Ouriz, \& Baptista, Yohanes. (2012). Identifikasi Plat Nomor Kendaraan Secara Off-Line Berbasis Pengolahan Citra dan Jaringan Syaraf Tiruan. ELECTRICIAN-Jurnal Rekayasa Dan Teknologi Elektro, 6(2), 123-126. Google Scholar

Hidayah, Maulidia Rahmah. (2017). Pengenalan nomor plat kendaraan dengan metode otsu dan klasifikasi k-nearest neighbour. Universitas Negeri Semarang. Google Scholar

Muchtar, Husnibes, \& Said, Fachri. (2019). Sistem Identifikasi Plat Nomor Kendaraan Menggunakan Metode Robert Filter dan Framing Image Berbasis Pengolahan Citra Digital. RESISTOR (ElektRonika KEndali TelekomunikaSI Tenaga LiSTrik KOmputeR), 2(2), 105-112. Google Scholar

Rahmadhika, Muhammad Karunia, \& Thantawi, Ahmad Muhammad. (2021). Rancang Bangun Aplikasi Face Recognition Pada Pendekatan CRM Menggunakan Opencv Dan Algoritma Haarcascade. IKRA-ITH Informatika: Jurnal Komputer Dan Informatika, 5(1), 109-118. Google Scholar

Ruslianto, Ikhwan, \& Harjoko, Agus. (2011). Pengenalan Karakter Plat Nomor Mobil Secara Real Time. IJEIS, 1(2), 35-44.Google Scholar

Shih, Bih Yaw, Chen, Cheng Wu, Chen, Chen Yuan, \& Kuo, Jin Wei. (2012). A robust license plate recognition methodology by applying hybrid artificial techniques. International Journal Of Innovative Computing Information And Control, 8(10A), 6777-6785. Google Scholar

Singh, Raja Vikramdeep, \& Randhawa, Navneet. (2014). Automobile Number Plate Recognition AndExtraction Using Optical Character Recognition. International Journal of Scientific \& Technology Research, 3(10), 37-39. Google Scholar

Suharyo, Okol Sri, Rosyid, I. R. Daniel M., Promotor, C. O., \& Armono, D. R. Haryo D. (2017). Model Penentuan Lokasi Pangkalan Angkatan Laut Berbasis Sustainabilitas. Surabaya: Institut Teknologi Sepuluh Nopember. Google Scholar

Wakhidah, Nur. (2012). Deteksi Plat Nomor Kendaraan Bermotor Berdasarkan Area pada Image Segmentation. Jurnal Transformatika, 9(2), 55-63. Google Scholar 
Wang, Xiaoling, Meng, Li Min, Zhang, Biaobiao, Lu, Junjie, \& Du, K. L. (2013). A video-based traffic violation detection system. Proceedings 2013 International Conference on Mechatronic Sciences, Electric Engineering and Computer (MEC), 1191-1194. IEEE. Google Scholar

\section{Copyright holder :}

Jati Purnomo dan Maukar (2021)

First publication right :

Journal Syntax Idea

This article is licensed under:

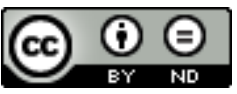

